\title{
A INSERÇÃO DO DIREITO AO VOTO DO ESTRANGEIRO NA AMÉRICA LATINA
}

\author{
THE INTRODUCTION OF THE RIGHT TO VOTE TO FOREIGNERS IN LATIN \\ AMERICA
}

\begin{abstract}
Gina Vidal Marcílio Pompeu
Possui graduação em Direito pela Universidade Federal do Ceará (1987), Mestrado em

Direito (Direito e Desenvolvimento) pela Universidade Federal do Ceará (1994) e

Doutorado em Direito pela Universidade Federal de Pernambuco (2004). Advogada inscrita na OAB -CE sob o n. 6101. Atualmente é Coordenadora e Professora do Programa de Pós-Graduação em Direito Constitucional da Universidade de Fortaleza, Mestrado e Doutorado, Professora convidada da Faculdade de Direito da Universidade do Havre, Professora Convidada da Faculdade de Jurisprudência da Universidade de Palermo. Pesquisadora de Pós-Doutorado das Faculdades de Direito da Universidade de Lisboa e do Havre. É membro associado do Conselho de Pesquisa e Pós Graduação em Direito - CONPEDI e da Associação Brasileira de Ensino do Direito ABEDi. E-mail: ginapompeu@unifor.br
\end{abstract}

Ana Carla Pinheiro Freitas Professora do Programa de Pós-Graduação em Direito Constitucional. E-mail: cpinheirofreitas@yahoo.com.br

Henrique dos Santos Vasconcelos Silva Mestrando do Programa de Pós-Graduação em Direito Constitucional. E-mail: henrivascon25@gmail.com

Recebido em: 21/08/2016

Aprovado em: 17/10/2016

Doi: $10.5585 / \mathrm{rdb} . v 15 i 6.487$

RESUMO: Por meio do presente artigo pretende-se abordar a inserção do direito ao voto do estrangeiro na América Latina e, em especial, no Brasil. Diante do cenário contemporâneo de globalização e intensificação dos fluxos migratórios revela-se necessário repensar a democracia, de forma a compatibilizá-la com os direitos humanos. Para tanto, deve-se medrar o rol de direitos aos estrangeiros, como instrumento capaz de permitir sua influência nas decisões que lhes afetem. A pesquisa parte da análise comparada do direito internacional e do constitucionalismo Latino-Americano. A experiência do constitucionalismo no ordenamento jurídico brasileiro é abordada levando-se em consideração as Propostas de Emenda à Constituição (PECS) relativas ao assunto. Desenvolve-se, no correr do texto, críticas argumentativas, posto que o acesso ao voto amplia a acessibilidade ao estrangeiro a direitos políticos. Por outro viés, persistem questionamentos relativos à soberania nacional e aos elementos básicos do Estado. A metodologia utilizada será a analítica, a empírica e a crítica.

Palavras-chave: Voto do estrangeiro; Cidadania. Soberania; America Latina. 


\begin{abstract}
The intention in this article is to examine the matter of granting active citizenship to foreigner individuals living in Brazil through guaranteeing the access to vote. In the contemporary scenario of globalization and increase of migratory flows, it becomes necessary to re-think democracy, in order to make it suitable to human rights. For such, it should thrive the list of rights of foreigners as an instrument capable of allowing to influence in the decisions that affect them. Under this perspective the analytical, empirical and critical methodology is used. The research starts from the comparative analysis of international law and Latin American constitutionalism. Later, it approaches the experience of constitutionalism in the Brazilian legal order, towards the Proposed Amendment to the Constitution (PECS). Lastly, it is known that the access to vote expands the possibilities of individuals entitled to political rights in a particular country. On the other hand, questions persevere regarding the national sovereignty and the basic elements of the state.
\end{abstract}

Keywords: Foreign Vote; Citizenship; Sovereignty; Latin America.

SUMÁRIO: Introdução; 1. O voto do estrangeiro nos países Latinos Americanos; 1.1. O ordenamento jurídico Argentino e os limites do voto do estrangeiro; 1.2. A Bolívia e o voto do estrangeiro; 1.3. O ordenamento jurídico da Colômbia: Os limites e as pontes para o voto do estrangeiro; 1.4. As constituições do Equador, Paraguai, Peru e Venezuela: Semelhanças e diferenças, no que tange ao voto do estrangeiro; 1.5. O voto do estrangeiro nas Américas do Sul e Central: Uma perspectiva geral; 2. Análise do voto do estrangeiro no Brasil: da PEC 61 de 1999 a PEC 347 de 2013; 3. A cidadania como instrumento de desenvolvimento das liberdades; Conclusão; Referências Bibliográficas.

\title{
INTRODUÇÃO
}

O mundo contemporâneo tem presenciado transformações nas mais diversas áreas: socioeconômicas, tecnológicas, midiáticas, dentre outras, as quais afetam as interações políticas e sociais. Tais mudanças aliadas à escassez de recursos naturais e ao surgimento ou intensificação dos conflitos armados, em especial, na Líbia, Síria, Afeganistão ocasiona aumento significativo do fluxo migratório.

A chamada globalização se impõe na seara econômica, no entanto, quando o contingente de migrantes não preenche o perfil econômico do país receptor, as fronteiras aos migrantes se fecha sob o argumento da soberania e da repercussão que o aumento da população pode gerar aos seus nacionais.

Diante desse cenário, mostra-se relevante desenvolver mecanismos de inserção do migrante na comunidade no sentido de sua proteção e integração para promover, não somente sua participação no mercado de trabalho, mas também na vida social e política do país. Lembrando que é objetivo fundamental da República Federativa do Brasil, "promover o bem de todos, sem preconceito de origem, raça, sexo, cor, idade e quaisquer outras formas de discriminação" (art. $3^{\circ}$, IV).

A partir do panorama apresentado, objetiva-se analisar o voto do estrangeiro como ferramenta de integração e potencialização de suas capacidades, com ênfase no estudo comparado das Constituições de diversos países da América Latina, Projetos de Lei e Propostas de Emenda à Constituição debatidos no Brasil. Far-se-á uma análise dos argumentos favoráveis e contrários à participação política dos migrantes, tendo como embasamento principal a promoção da dignidade humana, presente nas Declarações, Convenções Internacionais e fundamento da Constituição brasileira de 1988 (art. $1^{\circ}$, III). 
Abordar-se-á, também, o dever de cooperação mútua por parte dos Estados (art. $4^{\circ}$, IX da Constituição de 1988). Demonstrar-se-á a importância do movimento em prol do fomento a instrumentos que incluam o estrangeiro (migrante) no exercício ativo da cidadania.

Conferir direito de participação política a essas pessoas, significa permitir que elas atuem no âmbito das decisões políticas. Representa, portanto, o amadurecimento das instituições democráticas que, ao ampliar o rol de participantes do processo democrático, permite a interferência dos mesmos nos assuntos públicos que lhes afetam uma vez que, tal qual os nacionais residem, trabalham, pagam impostos e contribuem para a promoção da República Federativa do Brasil.

\section{O VOTO DO ESTRANGEIRO NOS PAÍSES LATINOS AMERICANOS}

Inicialmente, busca-se discorrer acerca da importância do exercício do voto pelo estrangeiro, intuído, criado e ratificado por acordos internacionais relevantes, como a Convenção de Direito Internacional Privado de 1928, Declaração Universal dos Direitos Humanos de 1948 e Pacto Internacional dos Direitos Civis e Políticos de 1966. Também o estudo, no sentido de apontar a inserção e o conteúdo das disposições acerca do voto do estrangeiro nas Constituições dos Estados Latino-Americanos serve para instigar a assunção de um posicionamento do nosso próprio ordenamento jurídico acerca do assunto.

No que diz respeito ao Direito Internacional Privado, tem-se uma importante convenção Convém lembrar, denominada Convenção de Direito Internacional Privado de $1928^{1}$, mais conhecida como Código de Bustamante. O referido Código alude logo no artigo $1^{\circ}$ que os estrangeiros gozam dos mesmos direitos civis que os nacionais. Já o artigo $2^{\circ}$ versa sobre a igualdade de garantias individuais, porém, faculta restrições constitucionais e legais, no que concernem ao exercício das funções públicas, ao direito de sufrágio e outros direitos políticos, salvo o disposto na legislação interna.

Conforme apontado acima, o Código Bustamante data de 1928. No entanto, o mesmo ainda serve de importante referência, já que aborda o direito de sufrágio. Nessa esteira, tem-se que, diante de comunidades cada vez mais plurais e miscigenadas do século XXI, resultado do processo de migrações internacionais, os Estados do mundo ocidental tendem a albergar novas leis que ampliem as perspectivas de inserção do migrante na vida política, assim como tendem igualmente a revisarem as suas constituições no sentido de garantir a participação política da categoria de estrangeiros residentes.

A vertente a favor da isonomia entre nacionais e migrantes é ressaltada na Declaração Universal dos Direitos Humanos de $1948^{2}$, ao estabelecer no artigo $2^{\circ}$ que "todos os seres humanos podem invocar os direitos e liberdades prescritos na presente Declaração". Ao mesmo tempo, a declaração veda distinções em razão do estatuto político, jurídico ou internacional do país ou do território da nacionalidade da pessoa. Soma-se a isso o disposto no artigo 21, da mesma Declaração, que consagra os princípios democráticos que garantem a todos o direito de participar, por intermédio do voto, diretamente, ou através de representantes, nos assuntos públicos.

Ademais, o Pacto Internacional sobre Direitos Civis e Políticos de $1966^{3}$ veda no artigo $2^{\circ}$ discriminações em virtude de origem nacional ou social, nascimento ou qualquer outra distinção e garante aos cidadãos do país, no artigo 25 o direito de participar dos assuntos públicos, de votar e ser eleito em eleições periódicas.

\footnotetext{
1 Disponível em:< http://www2.camara.leg.br/legin/fed/decret/1920-1929/decreto-18871-13-agosto-1929-549000publicacaooriginal-64246-pe.html>. Acesso em: 04 abr. 2016.

${ }^{2}$ Disponível em: $<$ http://www.ohchr.org/EN/UDHR/Documents/UDHR_Translations/por.pdf $>$. Acesso em: 04 abr. 2016.

${ }^{3}$ Disponível em:<http://www.planalto.gov.br/ccivil 03/decreto/1990-1994/d0592.htm>. Acesso em: 04 abr. 2016.
} 
Nessa vertente, na perspectiva do Direito Internacional, conforme se depreende das Declarações e Convenções em comento, uma evolução do pensamento em torno do direito ao voto do estrangeiro é remarcada. Desde o Século XX o ordenamento jurídico supranacional demonstra a preocupação em assegurar aos estrangeiros o direito de participar da vida política e das decisões públicas. Tal inquietude intensificou-se em razão do deslocamento forçado de judeus e europeus durante a II Guerra Mundial, na qual, muitos migraram para os Estados Unidos da América e países da América do Sul, como o Brasil.

Nesse contexto, para Dahl ${ }^{4}$ a democracia é um processo de progressiva ampliação da participação política. Diante dessa ótica, faz parte do processo democrático, compatibilizar o direito ao voto do estrangeiro com a realidade dos direitos humanos, conforme se percebe diante do Constitucionalismo Latino-Americano.

Nessa lógica, pontua-se que o voto do estrangeiro é tema presente nas diversas Constituições dos países latino-americanos. Note-se que a Argentina, Bolívia, Chile, Colômbia, Equador, Uruguai, Paraguai, Peru e Venezuela, ou seja, a quase totalidade dos países sulamericanos, à exceção do Brasil, permite o voto do estrangeiro.

\subsection{O ordenamento jurídico argentino e os limites do voto do estrangeiro}

Nessa acepção, a Constituição da Argentina $^{5}$ estabelece no artigo 20 que o estrangeiro goza, no território nacional, dos mesmos direitos civis dos cidadãos. Outrossim, o artigo 11, da Lei $n^{\circ} 25.871^{6}$, promulgada em 2004 facilita a consulta ou a participação dos estrangeiros nas decisões relativas à vida pública e à administração das comunidades locais, onde eles residem.

Complementarmente, é necessário destacar que na Argentina cada província regula suas eleições, nesse viés, conforme a legislação local, o estrangeiro residente poderá votar nas eleições municipais e provinciais. Por exemplo, na Cidade Autônoma de Buenos Aires, nas províncias de Buenos Aires, Córdoba e La Rioja é possível o voto do estrangeiro tanto nas eleições municipais, como nas provinciais. Já nas Províncias de Catamarca, Corrientes, Chaco, Chubut, Entre Rios, Jujuy, La Pampa, Mendonza, Misiones, Neuquém, Rio Negro, Salta, San Juan, Santa Cruz, Santa Fé, Santiago del Estero, Tucumán e Tierra Del Fuego, Antártida e Islas del Antlântico Sur só é permitido o voto nas eleições municipais. Por fim, em Formosa, o estrangeiro não vota nem nas eleições municipais, nem nas provinciais. ${ }^{7}$

Acrescenta-se, que o artigo 62 da Constituição da Cidade Autônoma de Buenos Aires ${ }^{8}$, além de estabelecer o sufrágio livre, igual, secreto, universal e obrigatório, possibilita nos termos da lei que os estrangeiros residentes usufruam deste direito em igualdade de condições com os cidadãos argentinos. Na mesma linha, a província de Buenos Aires, desde 2009, com as modificações na Lei Provincial $n^{\circ} 14.086^{9}$, no artigo $1^{\circ}$ obriga o voto do estrangeiro inscrito nos registros eleitorais e com domicílio na Província.

Além disso, cumpre lembrar que, tramitou no Senado argentino o Projeto de Lei S-2696 de $2012^{10}$, apresentado pelos Senadores Anibal Fernández e Elena Corregido, que visava

\footnotetext{
${ }^{4}$ DAHL, Robert A., Poliarquia: participação e oposição. São Paulo: Editora da Universidade de São Paulo, 2005.

${ }^{5}$ Disponível em:<http://www.senado.gov.ar/Constitucion/capitulo1>. Acesso em: 04 abr. 2016.

${ }^{6}$ Disponível em:<http://infoleg.mecon.gov.ar/infolegInternet/anexos/90000-94999/92016/norma.htm>. Acesso em: 04 abr. 2016.

7 Disponível em: $\langle$ http://www.elecciones.gob.ar/articulo_princ.php?secc=1\&sub_secc=44 $>$. Acesso em: 04 abr. 2016.

${ }^{8}$ Disponível em: $<$ http://infoleg.mecon.gov.ar/?page id=166 $>$. Acesso em: 04 abr. 2016.

${ }^{9}$ Disponível em: $<$ http://www.juntaelectoral.gba.gov.ar/docs/LEY14086.pdf $>$. Acesso em: 04 abr. 2016.

${ }^{10}$ Disponível em: $<$ http://www.argentinaelections.com/wp-content/uploads/2012/10/11719.pdf $>$. Acesso em: 04 abr. 2016.
} 
possibilitar o voto do estrangeiro residente permanente, a partir dos 16 anos. Tinha como esteio os termos da Lei $n^{\circ}$ 25.871. No entanto, o supracitado projeto de lei não veio a prosperar.

\subsection{A Bolívia e o voto do estrangeiro}

No que se refere à Constituição da Bolívia $^{11}$, esta estabelece no artigo 14 que os estrangeiros em território boliviano possuem os mesmos direitos e deveres assegurados aos nacionais, com exceção das restrições disciplinadas no texto constitucional. Ademais, o artigo 27, II afirma que os estrangeiros residentes possuem direito a voto nas eleições municipais, nos termos da lei e dos princípios de reciprocidade internacional. Nessa vertente, o Código Eleitoral Boliviano $^{12}$ (Lei $\mathrm{n}^{\circ} 1.984$, de 25 de junho de 1999) estabelece no artigo 93 a obrigatoriedade do voto nas eleições municipais, dos cidadãos homens e mulheres e dos estrangeiros residentes a pelo menos dois anos e registrados no Padrão Nacional Eleitoral. No mesmo sentido, a lei ${ }^{\circ}$ 026, de 30 de junho de 2010 (Lei do Regime Eleitoral ${ }^{13}$ ), define no artigo 45 como eleitor, nas eleições municipais, o estrangeiro residente no município por pelo menos dois anos.

\subsection{O ordenamento jurídico da Colômbia: os limites e as pontes para o voto do estrangeiro.}

$\mathrm{O}$ voto do estrangeiro na Constituição Colombiana ${ }^{14}$ encontra respaldo no artigo 100 . Este artigo garante igualdade de direitos civis entre estrangeiros e nacionais, ressalvados os que por motivos de ordem pública, a lei possa restringir ou negar. Por fim, no que se refere aos direitos políticos, a Constituição ressalta, que lei pode conceder ao estrangeiro o direito ao voto nas eleições e consultas populares municipais e distritais.

Nesse diapasão, a Sentença da Corte Constitucional colombiana $n^{\mathbf{o}}$ C238/06 ${ }^{15}$, que apreciou a constitucionalidade da Lei estatutária no 285/2005 do Senado e $n^{\text {o }}$ 129/2004 da Câmara, determinou que as mesmas cumpriam plenamente com as normas constitucionais e legais que regulam as regras do sufrágio pelo estrangeiro. Este deve ser residente ininterrupto por pelo menos cinco anos, possuir carteira de identidade de estrangeiro e registro eleitoral.

Além do mais, a Lei $\mathrm{n}^{\mathrm{o}} 1.070$, de $2006^{16}$, estabelece nos artigos $1^{\circ}$ e $2^{\circ}$ que o estrangeiro pode participar das eleições e consultas populares de caráter municipal e distrital, em que possuam domicílio. Nesse diapasão, cabe ao estrangeiro eleger os seguintes políticos: prefeito distrital e municipal, conselhos distritais e municipais e Juntas administradoras locais, distritais e municipais em todo o território nacional

\subsection{As Constituições do Equador, Paraguai, Peru e Venezuela: semelhanças e diferenças, no que tange ao voto do estrangeiro.}

Não menos importante é a Constituição do Equador ${ }^{17}$, tanto por estabelecer a igualdade de direitos e deveres entre estrangeiros residentes e equatorianos, bem como por permitir no

11 Disponível em: < http://www.harmonywithnatureun.org/content/documents/159Bolivia\%20Consitucion.pdf>. Acesso em: 04 abr. 2016.

${ }^{12}$ Disponível em: < http://www.lexivox.org/norms/BO-L-1984.xhtml>. Acesso em: 04 abr. 2016.

${ }_{13}^{13}$ Disponível em: < http://pdba.georgetown.edu/Electoral/Bolivia/Ley26-2010.pdf>. Acesso em: 04 abr. 2016.

$14 \quad$ Disponível em: < http://www.procuraduria.gov.co/guiamp/media/file/Macroproceso\%20Disciplinario/Constitucion_Politica_de_Colo mbia.htm>. Acesso em: 04 abr. 2016.

${ }^{15}$ Disponível em:< http://corteconstitucional.gov.co/relatoria/2006/C-238-06.htm>. Acesso em: 04 abr. 2016.

${ }^{16}$ Disponível em: $<$ http://54.226.140.140/migracion/docs/pdf/ley 1070_2006.pdf $>$. Acesso em: 04 abr. 2016.

${ }^{17}$ Disponível em:< http://www.asambleanacional.gov.ec/documentos/constitucion_de_bolsillo.pdf >. Acesso em: 04 abr. 2016. 
artigo 63 o direito ao voto do estrangeiro residente legalmente por mais de cinco anos nas eleições locais, regionais e nacionais, no entanto, não possibilita a candidatura.

Em sentido semelhante, a Constituição do Uruguai ${ }^{18}$ traz no artigo 78 , critérios objetivos a serem observados pelo estrangeiro para participar das eleições, tais como: boa conduta, família constituída na República, possuir capital de giro ou propriedade no país ou ao professar alguma ciência, arte ou indústria, ter residência habitual por pelo menos 15 anos na República e registro no Cartório de Registro Civil.

Indo além, a Constituição Paraguaia ${ }^{19}$, no capítulo $X-$ Dos direitos e dos deveres políticos, especificamente, no artigo 120, que trata dos eleitores, permite o voto nas eleições municipais, do estrangeiro com residência definitiva e dezoito anos de idade.

Cabe destacar que a Constituição do $\operatorname{Peru}^{20}$ é omissa no que se refere ao voto do estrangeiro. Apesar disso, o artigo $7^{\circ}$ da Lei $n^{\circ} 26.864^{21}$ (Lei de Eleições Municipais) assegura ao estrangeiro maior de 18 anos e residente por mais de dois anos contínuos, o direito a votar e ser votado, desde que, devidamente inscrito no registro competente, exceto nos municípios de fronteira.

Além disto, a Constituição venezuelana ${ }^{22}$ possibilita no artigo 64 o exercício do voto pelos estrangeiros com idade superior a 18 anos e com mais de 10 anos de residência no país, nas eleições municipais, paroquiais e estaduais, ressalvada as limitações legais e constitucionais, tais como, a interdição civil ou inabilitação política.

\subsection{O voto do estrangeiro nas Américas do Sul e Central: uma perspectiva geral}

A preocupação com a cidadania, a democracia e a dignidade humana é recorrente nas constituições dos países da América do Sul, por sua íntima relação com as Declarações e Convenções internacionais, ao preconizarem direitos e deveres iguais entre estrangeiros e nacionais e permitirem o sufrágio do migrante. No entanto, em muitos países tal direito é restrito às eleições municipais, sem o direito de se candidatar e com residência definitiva por certo período de tempo, o que já constitui um avanço. Nesse contexto, Bolívia, Equador e Peru revelam amadurecimento democrático, ao possibilitarem, respectivamente, a obrigatoriedade do voto; estender o sufrágio para as eleições nacionais; e por facultar que o estrangeiro seja candidato.

Não obstante a quase totalidade dos países sul-americanos, promoverem a integração e inserção do migrante, ao ampliar o exercício da cidadania, os países da América Central (Costa Rica, Cuba, El Salvador, Guatemala, Haiti, Honduras, Nicarágua, Panamá e República Dominicana) e da América do Norte (México) não salvaguardam o direito ao voto do estrangeiro.

Contrapondo-se às Constituições que permitem o voto do estrangeiro, a Constituição da

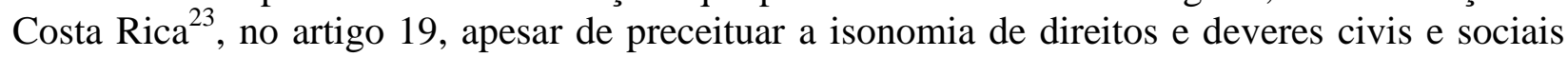
entre estrangeiros e costarriquenhos, estabelece exceções e limitações constitucionais e legais, dentre tais, a vedação do estrangeiro de intervir nos assuntos políticos do país.

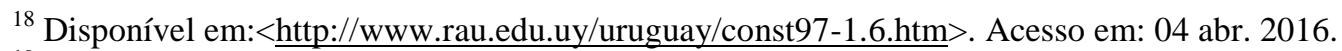

${ }^{19}$ Disponível em:< http://www.oas.org/juridico/spanish/par_res3.htm>. Acesso em: 04 abr. 2016.

${ }^{20}$ Disponível em:<http://www4.congreso.gob.pe/ntley/Imagenes/Constitu/Cons1993.pdf>. Acesso em: 04 abr. 2016.

${ }^{21}$ Disponível em: $<$ http://pdba.georgetown.edu/Electoral/Peru/municipales.pdf $>$. Acesso em: 04 abr. 2016.

${ }^{22}$ Disponível em:< http://www.cne.gob.ve/web/normativa_electoral/constitucion/titulo3.php\#cap2sec2>. Acesso em: 04 abr. 2016.

23 Disponível em: UKEwikrZS2j4jGAhUKGIwKHZNQALI\&url=http\%3A\%2F\%2Fwww.hcostarica.fcs.ucr.ac.cr\%2Fcontenidos\%2Ft extos\%2Fconstituc.rtf\&ei=RL95VaT7JoqwsASToYGQCw\&usg=AFQjCNEipQi1rgTi8APpOMuTeDrcQOgdcA\&si g2=ElHH0TrOjzr5g1BwQMmZ4g\&bvm=bv.95277229,d.cWc>. Acesso em: 04 abr. 2016. 
No mesmo sentido, a Constituição cubana ${ }^{24}$ restringe, no artigo 132 , o direito ao voto aos cidadãos e cidadãs cubanos e cubanas maiores de 16 anos de idade. Da mesma forma, a Constituição da Guatemala ${ }^{25}$, ao tratar dos deveres e direitos políticos, preceitua no artigo 136 como deveres dos cidadãos: eleger e ser eleito; participar das atividades políticas.

Na mesma vertente, a Constituição do Panamá ${ }^{26}$, no Título IV (Direitos Políticos), no Capítulo I, da Cidadania, dispõe no artigo 131 que são cidadãos os panamenhos com mais de dezoito anos. Indo além, no Capítulo II, do Sufrágio, o artigo 135, estatui que o voto é livre, igual, universal, secreto e direto e, o sufrágio consiste em direito e dever restrito aos cidadãos. $\mathrm{Na}$ mesma vertente, o Código eleitoral panamenho ${ }^{27}$, no título I - sufrágio e padrão eleitoral, nos capítulos primeiro (princípios gerais) e segundo (dos eleitores), limita, nos artigos $1^{\circ}, 3^{\circ}$ e $6^{\circ}$, os direitos políticos aos cidadãos panamenhos.

Destaca-se que a Constituição de El Salvador ${ }^{28}$ é mais rigorosa com o migrante, pois, alude no artigo 97 que o estrangeiro que direta ou indiretamente participar da política interna do país perde o direito de residir nele. Ainda mais severa com o estrangeiro são as Constituições do Haiti $^{29}$ e de Honduras ${ }^{30}$ ao disporem, respectivamente, no artigo 56, a expulsão do estrangeiro que se imiscua na vida política do país do território nacional; e, no artigo 32 prevê sanções conforme a lei, ao estrangeiro que desenvolver no país atividades políticas nacionais ou internacionais.

Importa destacar que a Constituição mexicana ${ }^{31}$ apesar de não estabelecer penalidades assevera que o estrangeiro não pode imiscuir-se nos assuntos políticos do país (artigo 33). De igual forma, a Constituição da Nicarágua ${ }^{32}$, embora, comine isonomia de direitos e deveres entre estrangeiros e nicaraguense, no artigo 27 restringe os direitos políticos aos cidadãos, ao vedar que o estrangeiro intervenha nos assuntos políticos do país.

No mesmo sentido é o texto constitucional da República Dominicana ${ }^{33}$ que também estabelece direitos e deveres iguais entre estrangeiros e nacionais, ressalvadas as exceções e limitações constitucionais e legais, dentre elas: participar da atividade política em território nacional.

$\mathrm{O}$ estudo das Constituições retro mencionadas revela retrocesso no que diz respeito à democratização dos direitos políticos dos estrangeiro. Isso se dá nas mais diversas formas, como por exemplo ao impossibilitar o exercício do voto pelo estrangeiro que não se alinham aos princípios contidos no Direito Internacional elencados nos documentos internacionais referidos no início deste tópico. Elas se distanciam, com isso, da realidade social contemporânea, marcada pelo crescimento dos fluxos migratórios, da pluralidade e diversidade de raças, culturas, religiões, nacionalidades. A propósito, Dahrendorh ${ }^{34}$ alude que uma sociedade civilizada é aquela em que os direitos inerentes a cidadania compatibiliza com o pluralismo de raças, religiões e culturas.

\footnotetext{
${ }^{24}$ Disponível em:< http://www.cuba.cu/gobierno/cuba.htm>. Acesso em: 04 abr. 2016.

${ }^{25}$ Disponível em:<https://www.oas.org/juridico/mla/sp/gtm/sp_gtm-int-text-const.pdf $>$. Acesso em: 04 abr. 2016.

26 Disponível em:< http://www.unesco.org/culture/natlaws/media/pdf/panama/pan_constpol_04_spaorof $>$. Acesso em: 04 abr. 2016.

${ }^{27}$ Disponível em:<http://pdba.georgetown.edu/Electoral/Panama/pancode.html>. Acesso em: 04 abr. 2016.

${ }^{28}$ Disponível em:<http://www.constitution.org/cons/elsalvad.htm>. Acesso em: 04 abr. 2016.

${ }^{29}$ Disponível em:< http://parliament.gov.gy/constitution.pdf>. Acesso em: 04 abr. 2016.

http://www.poderjudicial.gob.hn/CEDIJ/Leyes/Documents/Constituci\%C3\%B3n\%20de\%20la\%20Rep\%C3\%BAblic a\%20de\%20Honduras\%20(Actualizada\%202014).pdf>. Acesso em: 04 abr. 2016.

${ }^{31}$ Disponível em:<http://www.diputados.gob.mx/LeyesBiblio/htm/1.htm>. Acesso em: 04 abr. 2016.

http://legislacion.asamblea.gob.ni/Normaweb.nsf/3133c0d121ea3897062568a1005e0f89/06c0db3b7bcfc7570625730 7006f6c6d?OpenDocument>. Acesso em: 04 abr. 2016

${ }^{33}$ Disponível em: $<$ http://www.ifrc.org/docs/idrl/751ES.pdf $>$. Acesso em: 04 abr. 2016.

${ }^{34}$ DAHRENDORF, R. O conflito social moderno: um ensaio sobre a política de liberdade. Rio de Janeiro: Zahar, 1992.
} 
Nessa vertente, também Marc Augé ${ }^{35}$ aponta para a ilusão de uma comunidade sem o respeito à alteridade.

Na conjuntura do século XXI, cumpre relembrar e apontar a atualidade do clássico "dever de hospitalidade" proclamado por Kant ${ }^{36}$ no século XVIII. O citado dever de hospitalidade significava que os Estados teriam de acolher e de promover a integração do estrangeiro, por intermédio da cidadania ativa e passiva de tais indivíduos, uma vez que, trabalham, residem, pagam impostos, contribuem para a formação cultural, política e socioeconômica dos municípios em que habitam.

Após a abordagem teórica do direito de voto, assim como da abordagem específica do tema no ordenamento jurídico dos países da América Latina e da América Central, busca-se no capítulo que se segue examinar o status quo do voto do estrangeiro no Brasil, que tornou necessárias propostas de emendas à Constituição existente, com o intuito de fortalecer a democracia e a participação política, como instrumento de ampliação da cidadania.

\section{ANÁliSE DO VOTO DO ESTRANGEIRO NO BRASIL: DA PEC 61 DE 1999 A PEC 347 DE 2013}

Preliminarmente, a título de contextualização do tema, o Código de Bustamante (Convenção de Direito Internacional Privado, de Havana, de 1928) foi recepcionado pelo Brasil por meio do Decreto $\mathrm{n}^{\circ}$ 5.647, de 08 de janeiro de 1929, anteriormente assinada pelo Congresso Nacional em 20 de fevereiro de 1928 e promulgada pelo Decreto $\mathrm{n}^{\mathbf{0}} 18.871$, de 13 de agosto de 1929.

Já o Pacto Internacional sobre Direitos Civis e Políticos, de 1966 foi aprovado na ordem interna pelo Congresso Nacional por intermédio do Decreto Legislativo $\mathrm{n}^{\mathbf{0}} 226$, de 12 de dezembro de 1991, promulgado pelo Decreto n ${ }^{\circ} 592$, de 6 de julho de 1992 e, em vigor, desde 24 de janeiro em 1992.

Ademais, a Constituição Federal de $1988^{37}$ ao tratar dos preceitos fundamentais, apresenta como um dos fundamentos da República Federativa do Brasil, a cidadania (artigo $1^{\circ}$, II). O mesmo artigo, em seu parágrafo único concebe que todo o poder emana do povo, cujo exercício pode se dar diretamente ou por meio de representantes eleitos. Além do mais, o artigo $5^{\circ}$ não faz distinção entre nacionais e estrangeiros residentes. Por fim, o artigo 60, parágrafo $4^{\circ}$ estabelece o voto direto, secreto, universal e periódico como cláusula pétrea.

Nesse âmbito, faz-se necessário ressaltar o posicionamento sobre as alterações as cláusulas pétreas. Nessa seara há quem argumente que modificações nas cláusulas pétreas retiraria a rigidez constitucional ${ }^{38}$. Contudo, há doutrinadores que defendem a tese da dupla revisão (Jorge Miranda, Duguit, Manoel Gonçalves Ferreira Filho) por acreditarem que as cláusulas pétreas possuem eficácia relativa. Tais pensadores acreditam que as cláusulas pétreas não podem ser abolidas, mas podem ser modificadas, alteradas e regulamentadas. ${ }^{39}$

Nesta seara, não possibilitar o direito ao sufrágio do estrangeiro sob o argumento da impossibilidade de modificação das cláusulas pétreas além de "engessar" o ordenamento jurídico, vai de encontro ao princípio democrático do exercício da cidadania, aos inúmeros documentos internacionais de direitos humanos recepcionados pelo ordenamento jurídico nacional e à Constituição brasileira vigente. Diante dessa argumentação tem-se que a ampliação do voto ao

\footnotetext{
${ }^{35}$ AUGÉ, Marc. La Communauté illusoire. Paris: Rivages poche, 2010.

${ }^{36}$ KANT, Immanuel. À paz perpétua. Porto Alegre: L\&PM, 2008.

${ }^{37}$ Disponível em:〈http://www.planalto.gov.br//ccivil 03/constituicao/constituicao.htm>. Acesso em: 28 mar. 2016.

${ }^{38}$ BRITTO, Carlos Ayres. Teoria da constituição. Rio de Janeiro: Forense, 2003

${ }^{39}$ FERREIRA FILHO, Manoel Gonçalves. O poder constituinte. 3. ed. rev. e atual. São Paulo: Saraiva, 1999.
} 
estrangeiro não viola as cláusulas pétreas constantes no artigo 60, uma vez que, visa ao retrocesso da proteção de direitos fundamentais, e sim à ampliação ou atualização de tais direitos.

Cabe acrescentar, que o artigo $12, \S 1^{\circ}$ da Constituição brasileira garante a igualdade de direitos entre brasileiros e portugueses residentes permanentemente no país e sob a condição de haver reciprocidade em favor dos brasileiros. Nesse caso deve o cidadão Português requerer ao Ministério da Justiça o reconhecimento de tal direito, o qual poderá ser acatado por decisão do Ministro da Justiça, mediante Portaria. Assim sendo, temos que o português tem a possibilidade de votar, sem naturalizar-se brasileiro, desde que registrado no Cartório Eleitoral e munido da Portaria do Ministro da Justiça e da carteira de identidade, expedido no Brasil.

No entanto, trata-se de exceção, posto que, a regra contida no artigo $14, \S 2^{\circ}$ da Constituição brasileira veda o alistamento eleitoral do estrangeiro, salvo o caso de naturalização do estrangeiro residente da República Federativa do Brasil há mais de quinze anos ininterruptos e sem condenação penal.

Nessa vertente, apesar da Constituição de 1988 está atrelada à concepção de dignidade humana e de direitos fundamentais, todavia, em termos de inclusão dos migrantes, cidadania e democracia ainda há que se atualizar, no intuito de permitir a ampliação da participação nos assuntos públicos aos estrangeiros residentes. Nesse âmbito, a participação do migrante na vida política permitirá melhor representatividade de tal parcela da população, bem como, maior conscientização dos eleitores brasileiros, posto que, ao conceder voz a todos os indivíduos que residam no território nacional, ampliar-se-á o debate público e respeitar-se-á o pluralismo e cosmopolitismo das sociedades pós-modernas.

Ampliar a cidadania aos migrantes que aqui trabalham, residem e pagam seus impostos contribui para o fortalecimento das instituições democráticas e possibilita desenvolver o senso de estima por parte dos governantes, dos partidos políticos e do país como um todo. Além do mais, a nacionalidade brasileira é multicultural, haja vista o Brasil ser um país assentado sobre a participação estrangeira.

Nesta acepção, busca-se discorrer sobre as propostas de emenda à constituição (PEC's) 61/1999 e 7/2002, de autoria do Senador Alvaro Dias; 33/2002, de autoria do Senador Mozarildo Cavalcanti; 401/2005, proposta pelo Senador Orlando Fantazzini; 14/2007, cujo autor é o Senador Alvaro Dias; 88/2007, cuja propositura é do Senador Sérgio Zambiasi; 119/2011, de autoria do Deputado Roberto Freire; 25/2012, de proposição do Senador do Senador Aloysio Nunes Ferreira e 347/2013, de autoria do Deputado Carlos Zarattini, uma vez que, têm por objetivo permitir que os estrangeiros residentes participem dos assuntos políticos do país, ao conceder participação política a estes indivíduos. Dentre as PEC's em comento, segue em trâmite as PEC's 14/2007, 119/2011, 25/2012 e 347/2013.

A primeira Proposta de emenda à Constituição de 1988 sobre a matéria é a PEC $61 / 1999^{40}$. Tal PEC visava alterar os $\$ \S 2^{\circ}$ e $3^{\circ}$, do artigo 14 da Constituição, para permitir que o estrangeiro domiciliado no Brasil possa se alistar como eleitor nas eleições municipais e se candidatar a vereador, porém, a mesma foi emendada para que o período de residência seja de oito anos (emenda $\mathrm{n}^{\circ} 01$ ) e houvesse a exigência de reciprocidade (emendas $\mathrm{n}^{\circ} 02$ e 03 ).

Observa-se que no Parecer 713/2001, publicado no Diário do Senado Federal no 93, cuja relatoria ficou a cargo do Senador Bello Braga, assevera-se pela rejeição das emendas no 02 e 03 diante da inviabilidade da reciprocidade, por falta de condições de estabelecer os seus efeitos jurídicos. Nesses termos, como exemplo da falta de tratamento mútuo, cita-se o fato dos libaneses residentes no território brasileiro, que anseiam por tal direito, mas que diante do número ínfimo de brasileiros no Líbano inexistiria tratamento semelhante.

A contrário senso, é o parecer do ano 2000, do Senador Edison Lobão, que consta no já mencionado Diário do Senado Federal, por recomendar a aprovação da emenda $\mathrm{n}^{\circ} 03$, posto que,

${ }^{40}$ Disponível em:<http://www25.senado.leg.br/web/atividade/materias/-/materia/40987>. Acesso em: 04 abr. 2016. Revista de Direito Brasileira | São Paulo, SP | v. 15 | n. 6 | p. 61 - 82 | set./dez. 2016 
possibilita o alistamento e a candidatura a vereador do estrangeiro residente e domiciliado no Brasil por pelo menos 8 anos e desde que haja reciprocidade. Com a rejeição da PEC em comento em 04 de setembro de 2001, o Senador Alvaro Dias em 2002 concebe a PEC 7/2002 $2^{41}$, que faculta a participação do estrangeiro nas eleições municipais, apesar disso, a mesma foi arquivada em 22 de janeiro de 2007.

Vale ressaltar que, de forma mais ampla é a PEC 33/2002 ${ }^{42}$ que tinha por finalidade possibilitar não só o voto do estrangeiro residente, como a candidatura a qualquer cargo, com exceção dos preceituados no artigo 12, §3 da Constituição Federal de 1988 (Presidente e VicePresidente, Presidente da Câmara dos Deputados, Presidente do Senado). Tal PEC foi arquivada em definitivo em 11 de janeiro de 2011.

Já no ano de 2005 o Deputado Orlando Fantazzini criou a PEC 401/2005 ${ }^{43}$, cujo escopo era garantir o direito ao voto do estrangeiro residente no território brasileiro por mais de cinco anos, no entanto, a mesma não veio a prosperar, uma vez que, foi arquivada em 2007, conforme Diário da Câmara dos Deputados, de 1 de fevereiro de 2007.

No ano de 2007, o Senador Alvaro Dias propõe a PEC 14/2007 ${ }^{44}$, cuja finalidade era possibilitar o voto do estrangeiro domiciliado no Brasil, nas eleições municipais e a respectiva candidatura a vereador. A PEC 88/2007 $7^{45}$ de autoria do Senador Sérgio Zambiasi possibilitava o voto do estrangeiro residente no Brasil a mais de cinco anos e com dezesseis anos de idade.

Ressalta-se, que por força do Requerimento 926, de 2010 as $\operatorname{PEC(S)} \mathrm{n}^{\circ} \mathrm{S} 14$ e 88, passaram a tramitar em conjunto com a retro citada PEC no 33/2002 (arquivada em 2011). Em, 2013, por obra do Requerimento $\mathrm{n}^{\circ} 1272$, as $\operatorname{PEC}(\mathrm{S})$ em análise foram apensadas a PEC $\mathrm{n}^{\circ}$ 25/2012. Importa frisar, que desde 26 de fevereiro de 2015, a PEC $\mathrm{n}^{\mathbf{o}}$ 14, encontra-se na Comissão de Constituição, Justiça e Cidadania (CCJ) aguardando designação do relator. Contudo, a PEC no 88 foi arquivada em 26 de dezembro de 2014.

Compete ainda analisar a PEC no $119 / 2011^{46}$ de autoria do Deputado Roberto Freire, que tem como finalidades permitir a cidadania ativa ao estrangeiro domiciliado no Brasil e residente a mais de cinco nas eleições municipais e a cidadania passiva (candidatura) ao residente a no mínimo 10 anos. A PEC no 347/2013 (apensada a PEC $n^{\circ} 119 / 2011$ ), de autoria do Deputado Carlos Zarattini é mais restrita por se limitar a facultar o voto do estrangeiro com residência no país superior a quatro anos.

Cumpre destacar o escopo da PEC $\mathrm{n}^{\mathrm{o}} 25 / 2012^{47}$ por além de estender aos estrangeiros, independentemente de serem residentes ou não, o direito à vida, à liberdade, à igualdade, à propriedade e à segurança inerente aos nacionais, amplia o direito ao voto, ao possibilitar a candidatura, nas eleições municipais aos estrangeiros residentes no país.

Complementarmente, sublinha-se, que o Projeto de Lei $\mathrm{n}^{\mathrm{o}} 5.655 / 2009^{48}$, de autoria do Poder Executivo e apensado ao Projeto de Lei $n^{\circ} 2.516 / 2015$, permite avanços em relação a Lei $\mathrm{n}^{\circ}$ 6.815, de 19 de agosto de $1980^{49}$ (Estatuto do Estrangeiro), sob a égide da Constituição de 1967, que remota ao Regime Militar, posto que, a segurança nacional e os interesses políticos,

\footnotetext{
${ }^{41}$ Disponível em: $<$ https://www25.senado.leg.br/web/atividade/materias/-/materia/49571 >. Acesso em: 04 abr. 2016.

${ }^{42}$ Disponível em: $\langle$ http://www25.senado.leg.br/web/atividade/materias/-/materia/53316>. Acesso em: 04 abr. 2016.

43 Disponível em:<http://www.camara.gov.br/proposicoesWeb/fichadetramitacao?idProposicao=287461 >. Acesso em: 04 abr. 2016.

${ }^{44}$ Disponível em: $<$ http://www25.senado.leg.br/web/atividade/materias/-/materia/80077>. Acesso em: 04 abr. 2016.

${ }^{45}$ Disponível em:<http://www25.senado.leg.br/web/atividade/materias/-/materia/82695 >. Acesso em: 04 abr. 2016.

46 Disponível em:<http://www.camara.gov.br/proposicoesWeb/fichadetramitacao?idProposicao=530024>. Acesso em: 04 abr. 2016.

${ }^{47}$ Disponível em: $\langle$ http://www25.senado.leg.br/web/atividade/materias/-/materia/105568 $>$. Acesso em: 04 abr. 2016.

${ }^{48}$ Disponível em: 〈http://www.camera.gov.br/proposicoesWeb/fichadetramitacao?idProposicao=443102 >. Acesso em: 28 mar. 2016.

${ }^{49}$ Disponível em:〈http://www.planalto.gov.br/ccivil_03/leis/16815.htm>. Acesso em: 28 mar. 2016.
}

Revista de Direito Brasileira | São Paulo, SP | v. 15 | n. 6 | p. 61 - 82 | set./dez. 2016 
socioeconômicos e culturais do Brasil dão lugar a garantia dos direitos humanos e ao fortalecimento das instituições democráticas e das relações internacionais.

Dessa forma, o Projeto de Lei em análise se mostra em conformidade com a PEC $n^{\circ}$ 25/2012, por garantir ao estrangeiro residente, permanente ou de forma temporária uma série de direitos, tais como: igualdade de direitos civis e sociais com os nacionais, direito de associação, e os estabelecidos no caput do artigo $5^{\circ}$ da Constituição Federal de 1988. Não obstante, veda no artigo $8^{\circ}$ o exercício de atividade político-partidária.

De forma mais ampla, o Projeto de Lei ${ }^{\circ} 2.516 / 2015^{50}$, de autoria do Senador Aloysio Nunes Ferreira, originário do Projeto de Lei do Senado $n^{\circ} 288 / 2013$, possui um alinhamento maior com os direitos humanos, ao dispor no artigo $3^{\circ}$, a universalidade, indivisibilidade e interdependência dos direitos humanos (inciso I), repúdio e prevenção à xenofobia, ao racismo e a qualquer forma de discriminação (inciso II), acolhida humanitária (inciso VI), igualdade de tratamento e oportunidade (inciso IX), inclusão social (inciso X), promoção e difusão de direitos, liberdades, garantias e obrigações do migrante (inciso XII), integração econômica, política, social e cultural dos povos da América Latina (inciso XIV). Nessa vertente, alinha-se aos preceitos constitucionais da cidadania, não distinção, dignidade da pessoa humana e cooperação latino americana.

Neste âmbito, percebe-se, por meio da evolução do pensamento constitucional e infraconstitucional a relevância dos direitos humanos e fundamentais e, por conseguinte, da ampliação dos direitos ao estrangeiro, cuja temática tem pautado o debate social e político. Pelo exame das PEC(s) em comento, sublinha-se, que a reciprocidade, certo tempo de residência e a limitação a candidatura a certos cargos podem ser critérios a serem observados na ampliação da cidadania aos estrangeiros, por meio da participação na vida pública.

Acrescenta-se, que o direito de votar e ser votado faz parte do debate político desde o século passado. Tal cenário revela uma característica brasileira de protelar a resolução de questões de suma importância. A abolição da escravidão atesta tal afirmação, posto que, só em 13 de maio de 1888, com a Lei Áurea a escravidão foi extinta no Brasil. A abolição definitiva do regime escravocrata foi precedida pela Lei do Ventre Livre (lei n. ${ }^{\circ} 2.040$ ), de 28 de setembro de 1871 e a Lei do Sexagenário (lei n. ${ }^{\circ} 3.270$ ), de 28 de setembro de 1885.

Outrossim, o migrante é impedido de exercer os direitos políticos em seu país de origem, como de participar da vida política no estado de destino. Além do mais, contribuem para o desenvolvimento econômico e cultural das localidades em que habitam, para a formação da identidade nacional e lhes são conferidos de uma série de deveres iguais aos dos cidadãos: obediência às leis e contribuição compulsória, via impostos.

Como se pode observar é hora, pois, de acabar com tal discriminação negativa. Urge necessário dirimir a assimetria existente no fato de se exigir dos estrangeiros respeito à legislação dos países anfitriões, sem lhes dar, em contrapartida, alguns direitos políticos inerentes à pessoa humana. O direito de participar das eleições é um clamor que ecoa da voz dos migrantes que aqui residem. Tal reivindicação em São Paulo pode ser sintetizada pelo lema: "Aqui vivo, aqui voto".

Neste aspecto, ressalta-se a necessidade de alinhar os princípios constitucionais e democráticos e o fortalecimento das instituições políticas à realidade atual, ou seja, ao cenário de globalização, de enfraquecimento das fronteiras, crescimento dos fluxos migratórios e de transformações cada vez mais rápidas. É relevante conferir tratamento mais igualitário ao migrante, não só como forma de retribuir a enorme participação do migrante na construção do país, no seu desenvolvimento socioeconômico, mas também, de estreitar os vínculos afetivos, jurídicos e culturais entre estrangeiros e nacionais.

\footnotetext{
${ }^{50}$ Disponível em:〈http://www.camara.gov.br/proposicoesWeb/fichadetramitacao?idProposicao=1594910〉. Acesso em: 24 abr. 2016.
} 
O Estado Democrático de Direito não pode quedar-se inerte as necessidades contemporâneas: dar voz e voto aos estrangeiros sob sua jurisdição, revela-se a forma legítima de o migrante deixar de ser indivíduo de segunda categoria e transformar-se em cidadão ativo, capaz de influir nas políticas públicas que lhes digam respeito e assegurar atenção dos governantes as suas reivindicações, seja por habitação, segurança, saúde, educação.

Diante desse cenário, tenciona-se, no tópico à seguir discorrer de forma mais aprofundada sobre a cidadania, ao abordar os obstáculos ao voto do estrangeiro e, primordialmente, como as interações nas sociedades complexas em que habitamos e o contexto político e socioeconômico no qual estamos inseridos contribuem para potencializar as capacidades, permitem uma extensão da representatividade e auxiliam no repensar a cidadania, de forma a ampliar os direitos dos estrangeiros.

\section{A CIDADANIA COMO INSTRUMENTO DE DESENVOLVIMENTO DAS LIBERDADES}

Para se ter um conceito adequado e válido de cidadania e compreender melhor a problemática da soberania é preciso considerar os elementos formadores do Estado. Nesse sentido, a posição da doutrina (Bonavides ${ }^{51}$ ) considera que o estado é constituído de população, território e poder de mando. Diante desse cenário mostra-se significativo estabelecer a composição populacional dos migrantes em alguns países da América Latina (quadro 1), para que se possa desenvolver mecanismos de participação política do não cidadão (estrangeiro) de forma a compatibilizar cidadania e desenvolvimento.

QUADRO 1

\begin{tabular}{|c|c|c|c|c|c|c|c|c|}
\hline \multirow[b]{2}{*}{ Argentina } & \multirow{2}{*}{$\begin{array}{c}1990 \\
.649 .919 \\
\end{array}$} & \multicolumn{2}{|c|}{$\begin{array}{cc}2000 & 2010 \\
\text { NÚMERO DE PERSONAS }\end{array}$} & 2013 & \multicolumn{4}{|c|}{$\begin{array}{ccc}1990 & 2000 & 2010 \\
\% \text { DE LA POPULACIÓN TOTAL }\end{array}$} \\
\hline & & $.540 .219^{1}$ & $805.957^{1 .}$ & .885 .678 &, 1 &, 2 &, 5 &, 5 \\
\hline Bolivia & 9.590 & $9.058^{8}$ & $45.817^{1}$ & 54.330 & ,9 & 0 &, 4 & ,4 \\
\hline Brasil & 98.517 & $84.596^{6}$ & $92.568^{5}$ & 99.678 &, 5 &, 4 &, 3 &, 3 \\
\hline Chile & 07.501 & $77.332^{1}$ & $69.436^{3}$ & 98.251 & ,8 &, 1 & ,2 &, 3 \\
\hline Colombia & 04.277 & $09.609^{1}$ & $24.271^{1}$ & 29.632 &, 3 &, 3 &, 3 &, 3 \\
\hline Costa Rica & 17.628 & $10.946^{3}$ & $05.404^{4}$ & 19.572 & 3,6 &, 9 &, 7 & 6 \\
\hline Ecuador & 8.663 & $01.352^{1}$ & $25.668^{3}$ & 59.315 &, 8 &, 8 &, 2 &, 3 \\
\hline El Salvador & 7.360 & $1.713^{3}$ & $0.324^{4}$ & 1.615 &, 9 &, 5 & ,6 &, 7 \\
\hline Guatemala & 64.257 & $8.119^{4}$ & $6.384^{6}$ & 2.764 &, 0 &, 4 &, 5 &, 5 \\
\hline Haití & 9.084 & $5.832^{2}$ & $5.104^{3}$ & 8.061 &, 3 &, 3 &, 4 & ,4 \\
\hline Honduras & 70.423 & $8.461^{2}$ & $7.288^{2}$ & 7.503 &, 5 &, 5 &, 4 &, 3 \\
\hline México & 01.088 & $20.725^{5}$ & $62.516^{9}$ & .103 .460 &, 8 &, 5 & ,8 & ,9 \\
\hline Nicaragua & 0.792 & $0.545^{3}$ & $0.130^{4}$ & 1.482 &, 0 &, 6 &, 7 &, 7 \\
\hline
\end{tabular}

${ }^{51}$ BONAVIDES, Paulo. Ciência Política. 10 ed. São Paulo: Malheiros, 2000.

Revista de Direito Brasileira | São Paulo, SP | v. 15 | n. 6 | p. 61 - 82 | set./dez. 2016 


\begin{tabular}{|c|c|c|c|c|c|c|c|c|}
\hline Panamá & 1.681 & $6.391^{8}$ & $40.976^{1}$ & 58.417 & ,5 & 8 & 8 & ,1 \\
\hline Paraguay & 83.335 & $75.430 \quad 1$ & $81.728^{1}$ & 85.776 & ,3 &, 3 & ,8 & ,7 \\
\hline Perú & 5.993 & $9.937^{5}$ & $3.851^{9}$ & 04.919 & ,3 &, 2 &, 3 & ,3 \\
\hline $\begin{array}{c}\text { República } \\
\text { Dominicana }\end{array}$ & 91.151 & $55.611^{3}$ & $96.390^{3}$ & 02.506 & ,0 &, 1 & , 0 & ,9 \\
\hline Uruguay & 8.116 & $8.871^{8}$ & $6.263^{7}$ & 3.528 & , 2 &, 7 & ,3 &, 2 \\
\hline Venezuela & .023.259 & $.013 .531^{1}$ & 129.941. & .171.331 & ,2 & ,2 &, 9 &, 9 \\
\hline
\end{tabular}

Fonte: OEA. Migración internacional em las Américas: tercer informe del sistema continuo de reportes sobre migración internacional em las américas (SICREMI). Disponível em: 〈http://www.oas.org/docs/publications/SICREMI-2015-SPANISH.pdf>. Acesso em: 07 maio 2016.

Com base no quadro acima, com referência ao ano 2013, percebe-se que, dos 19 países analisados, a Costa Rica é quem tem a população composta por mais estrangeiros, com 8,6\%. Em dez nações o número de migrantes na população total não chega a $2 \%$. Nesse contexto, com o crescimento do fluxo migratório e, consequentemente, da crise humanitária é imperioso repensar a cidadania e a soberania, de maneira a compatibilizá-las com o cenário do século XXI.

Nesse contexto, cidadania não se restringe aos direitos políticos, ou seja, direito de votar e ser votado, direito de informação, direito de opinião. É com base nisso que se deve tomar consciência de que só haverá sociedade efetivamente justa quando houver educação cidadã em duplo sentido: no cumprimento das obrigações de respeitar os direitos dos outros e da conscientização dos próprios cidadãos da disposição de fazer valer esses direitos.

Como se pode perceber a cidadania é um dos pilares da sociedade porque está intrinsecamente associada aos conceitos de liberdade, igualdade, democracia e justiça, portanto, é status inalienável do homem moderno. Por outro lado, para ser efetivada pressupõe a participação popular e, além disso, que cada indivíduo cumpra com seus deveres e que tenham certos direitos assistidos pelo Estado.

Contemporaneamente cidadania deve ser entendida não apenas como direitos políticos (direito de votar, de ser votado); civis (propriedade, liberdade), mas, atualmente devem ser abarcados inclusive os direitos sociais (educação, trabalho) e os direitos humanos e coletivos. Hodiernamente a concepção de cidadania por conta da luta permanente pela proteção de um número mais extenso de direitos deve ser compreendida no seu conceito amplo, ou seja, como a constante união das pessoas para cumprirem suas obrigações e fazer valer seus direitos, na garantia de uma ordem equilibrada a todos os preceitos legislativos em vigor, quando legítimos, bem como de outros carentes de normatização.

Outorgar o direito de voto ao estrangeiro precisa ser visto não como uma extensão de direitos, mas na incorporação de um novo demos (estrangeiro), como uma redefinição da democracia, como forma de preservar a identidade histórica construída pelo estrangeiro. ${ }^{52}$

No mundo transnacional das sociedades ditas pós-modernas é preciso assegurar os direitos políticos às pessoas que vivem fora do seu país de origem. Nessa ótica revela-se indispensável repensar o processo democrático de maneira a possibilitar não só a atuação política. Nesse diapasão, a ampliação da cidadania é a maneira ideal de possibilitar não só o voto do estrangeiro, mas direitos como lazer, educação, saúde, moradia, cultura, liberdade de expressão, garantias constitucionais. Para tanto sublinha-se necessário analisar os principais argumentos favoráveis e contrários ao voto de tais indivíduos, como forma de garantir o princípio do sufrágio universal. 
As considerações favoráveis ao direito de voto pelo estrangeiro podem, com base na doutrina de Hayduk ${ }^{53}$, ser sistematizado nos seguintes pontos: o contrato social por ser fundado no consenso impõe que a autoridade do Estado advém do poder de escolha pelos governados. Nesse sentido, os cidadãos dão o consentimento aos governantes, por meio das eleições e dos mecanismos de fiscalização. Os obstáculos ao direito de voto discriminam os migrantes, pôr os colocarem em condição de invisibilidade. Não obstante, o voto de tais indivíduos favorece o senso de coletividade, uma vez que, a classe obreira e os afrodescendentes possuem demandas semelhantes.

Cumpre pontuar que o cumprimento de deveres, entre os quais o de pagar impostos, é condição sine qua non para o gozo de direitos políticos. A autoridade estatal vem da participação da sociedade não só nas escolhas, mas na manutenção e custeio da máquina pública. Além do mais, o voto do estrangeiro confere visibilidade a um grupo social discriminado. Os governantes só atenderão as demandas dos migrantes se estes tiverem voz, se fizerem parte da cena política, ademais, a cooperação, a ajuda mútua, o solidarismo reduzem conflitos e favorecem o senso de coletividade.

Acrescenta-se, ao trazer como exemplo dos Estados Unidos da América, que o voto do estrangeiro tem fundamento constitucional, por ser direito dos não cidadãos americanos, na maior parte do país, desde a fundação dos Estados Unidos até 1920. Há razões morais e práticas, uma vez que, estendem direitos e permite tratamento mais igualitário. Além do mais é realizável, inclusive, foi restabelecido recentemente em municípios como Maryland e Massachusetts nas eleições locais. No mesmo sentido é a reconsideração e debate em torno da reimplantação em outras jurisdições. $^{54}$

No que tange às justificativas para não concessão do voto ao estrangeiro, estas podem ser resumidas nas seguintes proposições: a naturalização é o meio automático de o migrante usufruir de tal direito; defesa da soberania nacional, posto que, o não cidadão pode votar conforme os interesses do seu país de origem; falta de conhecimento sobre o processo eleitoral e as instituições políticas podem comprometer o voto informado. Nesse sentido, Bodei ${ }^{55}$ estabelece que há quem parta de uma noção equivocada do estrangeiro, como estranho, extracomunitário. Como ameaça não só a soberania do país de acolhida, mas também, aos direitos e privilégios dos cidadãos. Em síntese, defende-se que o migrante se naturalize e respeite a autoridade política nacional.

Neste contexto, condicionar o voto do não cidadão à naturalização é despropositado, além disso, permitir que o estrangeiro vote sem ainda ser cidadão possibilita um estreitamento do vínculo com o país de destino. No que se refere ao argumento da soberania nacional, este demonstra-se infundado, na medida que, o estrangeiro tanto contribui para a formação da identidade nacional, para o desenvolvimento econômico e cultural do município que reside, bem como paga imposto e cumpre deveres. Ademais, o voto do não cidadão pode ser condicionado à reciprocidade.

No que concerne à soberania, Bonavides ${ }^{56}$ conceitua na esfera externa como uma qualidade do poder, que o estado pode ostentar ou não e no escopo interno como um conceito sócio jurídico atrelado à noção de suprema potestas - supremacia ou soberania estatal. Trata-se do predomínio da superioridade do ordenamento estatal como monopólio da coação estatal.

\footnotetext{
${ }^{53}$ HAYDUK, Ron. Democracy for all: restoring immigrant voting rights in the United States. New York: Routledge, 2006.

${ }^{54}$ HAYDUK, Ron. Democracy for all: restoring immigrant voting rights in the United States. New York: Routledge, 2006.

${ }^{55}$ BODEI, Remo. Los sin patria. In: GORSKI, Héctor C. Silveira. Identidades comunitarias y democracia. $1^{\text {a }}$ edição. Madrid: Trotta, 2000.

${ }^{56}$ BONAVIDES, Paulo. Ciência Política. 10 ed. São Paulo: Malheiros, 2000.
}

Revista de Direito Brasileira | São Paulo, SP | v. 15 | n. 6 | p. 61 - 82 | set./dez. 2016 
Nesse diapasão, Douzinas ${ }^{57}$ estabelece que a resistência ao estrangeiro, bem como, a má compreensão da situação do refugiado são as escusas que o estado tem para proteger sua soberania e dignidade. Para o autor o estrangeiro representa o trauma que origina o Estado e o $\mathrm{Eu}$, por implicar em uma crise às reivindicações de universalização dos direitos humanos.

Além do que, a noção de Estado-nação e de soberania, enquanto atributo inerente àquele ente, passa por transformações profundas, com o acirramento da globalização nas últimas décadas, caracterizada pela intensificação do fluxo transnacional de pessoas, valores e ideias. A soberania no contexto da globalização, dos fluxos migratórios e da integração regional precisa ser dirimida em razão da cidadania global, da cooperação entre países, da acolhida humanitária.

Ademais, Agamben ${ }^{58}$ entende, ainda, que "el refugiado y el exilado deben considererarse por lo que son, es decir, ni más ni menos que um concepto limite que pone em crisis radical las categorias fundamentales de la nación-estado, desde el nexo nacimiento-nación hasta el de hombre-ciudadano".

Corrobora com tal raciocínio, a afirmação de Bonavides ${ }^{59}$ de que tal crise parte da dificuldade de conciliar a concepção de soberania com a ordem internacional, cada vez mais visível diante do maior ou menor sacrifício do poder estatal ao ordenamento internacional. Tal limitação à soberania estatal é perceptível na formação de blocos de integração regional e na sujeição a jurisdição dos Tribunais Internacionais.

Nessa acepção, o crescente número de refugiados impõe um novo olhar sobre a cidadania e a democracia, ao pôr em crise a ficção originária da soberania. Diante dos conflitos bélicos, da crise humanitária e da globalização, imprime-se relevante que o estado à luz do direito fraterno assuma sua responsabilidade em tais eventos e, consequentemente, na inclusão dos indivíduos afetados, de modo a permitir não só a paz mundial, mas o pluralismo, o desenvolvimento humano e econômico, principalmente, por se tratar de pessoas em situação de vulnerabilidade e hipossuficiência.

Nesse sentido Douzinas ${ }^{60}$, ao tratar da alteridade, assevera que diante da singularidade, da dor e do sofrimento do estrangeiro há um dever moral, uma obrigação ética de salvá-lo, protegê-lo. Nessa vertente, a alteridade deve ser compreendida como uma reflexão individual a partir do outro, no tocante a ampliação dos direitos de cidadania, da participação política e dos direitos fundamentais como um todo.

Subsidiariamente, é indispensável que os compromissos e objetivos assumidos pelo Estado, desde a sua formação, coaduna com a solidariedade constitucional, posto que para a formação de uma sociedade cada vez mais heterogênea e plural, é inevitável vincular todos os órgãos estatais, potências públicas, cidadãos e grupos como entes participativos na formação dessa sociedade aberta a diversidade. ${ }^{61}$

O mesmo Häberle ${ }^{62}$ propõe a ideia de Estado Constitucional Cooperativo embasado em uma estrutura juridicamente delimitada e aberta, garantida pela democracia pluralista, direitos fundamentais, separação dos poderes e Poder Judiciário independente, e fundado em disposições constitucionais como "cooperação internacional", "paz no mundo", "direitos fundamentais como fundamento de toda sociedade humana". Tais noções devem ser consideradas conjuntamente com o aspecto sociológico-econômico, pois ao vincular o "bem comum", a escassez de recursos e a situação social das pessoas nos países em desenvolvimento obrigam os países a uma

\footnotetext{
${ }^{57}$ DOUZINAS, Costa. O fim dos direitos humanos. São Leopoldo: Unisinos, 2009.

58 AGAMBEN, Giorgio. Políticas del exilio. In: GORSKI, Héctor C. Silveira. Identidades comunitarias y democracia. $1^{\text {a }}$ edição. Madrid: Trotta, 2000, p. 87.

${ }^{59}$ BONAVIDES, Paulo. Ciência Política. 10 ed. São Paulo: Malheiros, 2000.

${ }^{60}$ DOUZINAS, Costa. O fim dos direitos humanos. São Leopoldo: Unisinos, 2009.

${ }^{61}$ HÄBERLE, Peter. Hermenêutica constitucional: a sociedade aberta dos intérpretes da constituição: contribuição para a interpretação pluralista e "procedimental" da constituição. Tradução Gilmar Ferreira Mendes. Porto Alegre: Sergio Antonio Fabris, 1997.

${ }^{62}$ HÄBERLE, Peter. Estado constitucional cooperativo. Rio de Janeiro: Renovar, 2007.
} Revista de Direito Brasileira | São Paulo, SP | v. 15 | n. 6 | p. 61 - 82 | set./dez. 2016 
responsabilidade comum. Nesse mesmo sentido Mises ${ }^{63}$ alude que "the ultimate yardstick of justice is conduciveness to the preservation of social cooperation".

Nessa linha de raciocínio, observa-se a imprescindibilidade da cooperação internacional, da fraternidade, do senso de responsabilidade dos países enquanto instituições globais como critério de justiça e de efetivação dos direitos humanos nas sociedades multiculturais e transnacionais.

A partir dessa afirmação, é preciso conjugar a solidariedade internacional com o desenvolvimento humano e a potencialização da agência. Nesse sentido, $\operatorname{Sen}^{64}$ afirma que o desenvolvimento só é possível com a eliminação das privações de liberdade que tolhem e limitam as escolhas e oportunidades dos indivíduos em influírem na sua condição de agente, no seu próprio destino. Nessa lógica O’Donnel ${ }^{65}$ alude que o exercício das capacidades, ou seja, de influenciar no seu próprio destino, de participar das decisões públicas e o gozo de direitos sem discriminações são determinantes para a democracia, a cidadania plena e a inclusão social.

Dessa forma, o voto do estrangeiro deve ser visto como meio e fim para a liberdade, de forma a contribuir para que tal indivíduo possa influir no seu próprio destino, por estar relacionado intimamente com a preocupação contemporânea e com os direitos fundamentais. Complementarmente, Bobbio ${ }^{66}$ assevera que, à medida que o poder econômico cada vez mais determina as decisões políticas e subordina as escolhas individuais, a participação em tal poder exige a participação no poder político.

Nesse diapasão, observa-se que o poder econômico, na perspectiva da atuação da agência, está intimamente relacionado à participação política. $\mathrm{O}$ desenvolvimento humano, $\mathrm{o}$ gozo de direitos e liberdades, a visibilidade social, o empoderamento do estrangeiro só é possível por meio da conjugação do poder econômico com o poder político.

Tal linha de pensamento encontra-se em consonância com o documento "Transformando Nosso Mundo: a Agenda 2030 para o Desenvolvimento Sustentável” da Organização das Nações Unidas $^{67}$ que estabelece os Objetivos de Desenvolvimento Sustentável (ODS), tem como viés: potencializar as capacidades humanas em matéria de igualdade e dignidade; garantir ambiente saudável, para que possam desfrutar de uma vida próspera e com plena realização pessoal.

Acrescenta-se a inquietude em promover sociedades pacíficas, justas e inclusivas, uma vez que é preciso paz para que tenha desenvolvimento sustentável. Dessa forma destaca-se o Objetivo $16^{68}$ : Promover sociedades pacíficas e inclusivas para o desenvolvimento sustentável; proporcionar o acesso à justiça para todos; e construir instituições eficazes, responsáveis e inclusivas em todos os níveis.

Nesse aspecto, destaca-se o Estado Cooperativo como instrumento de evolução da democracia, por encontrar sua identidade no Direito Internacional - ao vincular a ordem jurídica nacional - na percepção da cooperação, responsabilidade internacional e solidariedade. O Direito Fraterno corresponde a uma necessidade internacional de políticas de promoção da cidadania global como mecanismo de inserção social e de desenvolvimento das potencialidades do estrangeiro, tanto na expansão da concepção de cidadania, bem como, no desenvolvimento humano e crescimento econômico.

\section{CONCLUSÃO}

\footnotetext{
${ }^{63}$ MISES, Ludwig von. Theory and history. Connecticut: Yale University Press, 1957, p. 54.

${ }^{64}$ SEN, Amartya. Desenvolvimento como liberdade. São Paulo: Companhia das Letras, 2010, p. 10.

${ }^{65}$ O’DONNELL. Guillermo. Disonancias: críticas democráticas. Buenos Aires: Prometeo Libros, 2007.

${ }^{66}$ BOBBIO, Norberto. A era dos direitos. Rio de Janeiro: Elvesier, 2004.

${ }^{67}$ Disponível em: $<$ http://www.pnud.org.br/Docs/Agenda2030completo_PtBR.pdf $>$. Acesso em: 24 abr. 2016.

${ }^{68}$ Disponível em: $\langle$ http://www.pnud.org.br/Docs/Agenda2030completo_PtBR.pdf $>$. Acesso em: 24 abr. 2016.
}

Revista de Direito Brasileira | São Paulo, SP | v. 15 | n. 6 | p. 61 - 82 | set./dez. 2016 
Diante do histórico de exclusão do imigrante, há uma evolução no sentido da preocupação com os direitos humanos, conforme se depreende das normas de direito internacional - Convenção de Direito Internacional Privado de 1928, Declaração Universal dos Direitos Humanos de 1948, Pacto Internacional dos Direitos Civis e Políticos de 1966 e o documento "Transformando Nosso Mundo: a Agenda 2030 para o Desenvolvimento Sustentável".

No plano jurídico nacional, a Constituição Federal de 1988, Projetos de Lei n⿳s 5.655/2009 e 2.516/2015 coadunam com o amadurecimento da democracia e a necessidade de ampliação da cidadania aos migrantes, ao permitir que estes possam atendidos certos requisitos, votar e ser votados para cargos específicos.

Nesta perspectiva, países da América do Sul como Argentina, Bolívia, Chile, Colômbia, Equador, Uruguai, Paraguai, Peru e Venezuela permitem o voto do estrangeiro em maior ou menor amplitude. Já no cenário brasileiro, o tema está na pauta do Congresso Nacional desde 1999, o que revela uma postura conservadora em propiciar mudanças e reformas que ampliem o rol de direitos das minorias, tal como, na abolição da escravatura. Nesse contexto, foi preciso primeiro alforriar os mais novos, depois os mais velhos, para só assim libertar os demais. Ademais, no intuito de evitar repetir tais erros do passado, observa-se a necessidade de garantir ampla participação política aos estrangeiros, de forma a permitir votar e ser votado, à exceção dos cargos dispostos no artigo 12, § $3^{\circ}$ da Constituição Federal de 1988.

A contrário senso, países como Costa Rica, Cuba, El Salvador, Guatemala, Haiti, Honduras, Nicarágua, Panamá, República Dominicana e México não concede o direito de voto ao não cidadão seja por acreditar que a naturalização é o dispositivo para a atuação política e cidadã, bem como, como forma de proteção dos interesses e instituições nacionais. Em suma, trata-se de salvaguardar a soberania nacional.

Nesta acepção, acrescenta-se que a globalização tem enfraquecido as fronteiras, de modo a modificar a concepção de soberania e Estado Nação. Isso porque diante do fluxo de pessoas, ideias e valores cada vez mais rápidos e intensos, exige-se uma postura reflexiva sobre a noção de democracia, de maneira a compatibilizá-la com a realidade atual.

Nesse contexto, como forma de harmonizar o desenvolvimento das liberdades com o desenvolvimento humano e o crescimento econômico, é necessário possibilitar não só a participação na vida política, mas também a influência do estrangeiro em seu próprio destino, posto que, este paga imposto, contribui para o desenvolvimento local, a formação da identidade nacional e contribui para a manutenção e custeio do Estado. Além do que, as decisões políticas lhes afetam diretamente.

Por fim, destaca-se, o papel do Estado Cooperativo e do direito fraterno ao viabilizar a potencialização das capacidades do não cidadão, o desenvolvimento humano e o crescimento econômico, com fundamento na acolhida humanitária e no senso de responsabilidade internacional, nos termos do objetivo 16 da Agenda 2030 para o Desenvolvimento Sustentável. Nessa seara, é importante uma inserção social do migrante, calcada na cidadania global e na solidariedade, com o escopo de garantir a paz mundial e o bem comum.

\section{REFERÊNCIAS BIBLIOGRÁFICAS}

AGAMBEN, Giorgio. Políticas del exilio. In: GORSKI, Héctor C. Silveira. Identidades comunitarias y democracia. $1^{a}$ edição. Madrid: Trotta, 2000.

ARGENTINA. Voto de extranjeros residentes en Argentina. Disponível em: $<$ http://www.elecciones.gob.ar/articulo_princ.php?secc=1\&sub_secc=44 $>$. Acesso em: 04 abr. 2016. 
AUGÉ, Marc. La Communauté illusoire. Paris: Rivages poche, 2010.

BOBBIO, Norberto. A era dos direitos. Rio de Janeiro: Elvesier, 2004.

BODEI, Remo. Los sin patria. In: GORSKI, Héctor C. Silveira. Identidades comunitarias y democracia. $1^{\text {a }}$ edição. Madrid: Trotta, 2000.

BONAVIDES, Paulo. Ciência Política. 10 ed. São Paulo: Malheiros, 2000.

BRASIL. Constituição da República Federativa do Brasil de 1988. Disponível em: $<$ http://www.planalto.gov.br//ccivil_03/constituicao/constituicao.htm>. Acesso em: 28 mar. 2016.

BRASIL. Lei n. 6.815. de 19 de agosto de 1980 (Estatuto do Estrangeiro). Disponível em: $\leq$ http://www.planalto.gov.br/ccivil_03/leis/16815.htm>. Acesso em: 28 mar. 2016.

BRASIL. Proposta de Emenda à Constituição 61, de 1999. Disponível em: <http://www25.senado.leg.br/web/atividade/materias/-/materia/40987>. Acesso em: 04 abr. 2016.

BRASIL. Proposta de Emenda à Constituição 7, de 2002. Disponível em: $<$ http://www25.senado.leg.br/web/atividade/materias/-/materia/49571>. Acesso em: 04 abr. 2016.

BRASIL. Proposta de Emenda à Constituição 33, de 2002. Disponível em: $<$ http://www25.senado.leg.br/web/atividade/materias/-/materia/53316>. Acesso em: 04 abr. 2016.

BRASIL. Proposta de Emenda à Constituição 405, de 2005. Disponível em: $\lfloor$ http://www.camara.gov.br/proposicoesWeb/fichadetramitacao?idProposicao=287461 $>$. Acesso em: 04 abr. 2016.

BRASIL. Proposta de Emenda à Constituição 14, de 2007. Disponível em: $<$ http://www25.senado.leg.br/web/atividade/materias/-/materia/80077>. Acesso em: 04 abr. 2016.

BRASIL. Proposta de Emenda à Constituição 88, de 2007. Disponível em: $<$ http://www25.senado.leg.br/web/atividade/materias/-/materia/82695>. Acesso em: 04 abr. 2016.

BRASIL. Projeto de Lei n. 5.655, de 20 de julho de 2009. Disponível em: <http://www.camera.gov.br/proposicoesWeb/fichadetramitacao?idProposicao=443102>. Acesso em: 28 mar. 2016.

BRASIL. Proposta de Emenda à Constituição 119, de 2011. Disponível em: $\langle$ http://www.camara.gov.br/proposicoesWeb/fichadetramitacao?idProposicao=530024 $>$. Acesso em: 04 abr. 2016. 
BRASIL. Proposta de Emenda à Constituição 25, de 2012. Disponível em: $\lfloor$ http://www25.senado.leg.br/web/atividade/materias/-/materia/105568 >. Acesso em: 04 abr. 2016.

BRASIL. Projeto de Lei n. 6.300, de 30 de junho de 2013. Disponível em: $\lfloor$ http://www.camera.gov.br/proposicoesWeb/fichadetramitacao?idProposicao=591068 $>$. Acesso em: 28 mar. 2016.

BRASIL. Proposta de Emenda à Constituição 347, de 2013. Disponível em: $<$ http://www.camara.gov.br/proposicoesWeb/fichadetramitacao?idProposicao=599448 $>$. Acesso em: 04 abr. 2016.

BRASIL. Projeto de Lei $n$. 2.516, de 04 de agosto de 2015. Disponível em: $\langle$ http://www.camara.gov.br/proposicoesWeb/fichadetramitacao?idProposicao=1594910 $>$. Acesso em: 24 abr. 2016.

BRITTO, Carlos Ayres. Teoria da constituição. Rio de Janeiro: Forense, 2003.

Código Electoral, Bolívia. Ley 1984, de 25 de junho de 1999. Disponível em:< http://www.lexivox.org/norms/BO-L-1984.xhtml>. Acesso em: 04 abr. 2016.

Código Electoral, Panama. Disponível em:<http://pdba.georgetown.edu/Electoral/Panama/pancode.html>. Acesso em: 04 abr. 2016.

Constitución de la Republica de Cuba. Disponível em:< http://www.cuba.cu/gobierno/cuba.htm>. Acesso em: 04 abr. 2016.

Constitucion de la Republica de El Salvador. Disponível em:< http://www.constitution.org/cons/elsalvad.htm>. Acesso em: 04 abr. 2016.

Constitución de la Republica Dominicana. Disponível em: $\langle$ http://www.ifrc.org/docs/idrl/751ES.pdf $>$. Acesso em: 04 abr. 2016.

Constitución de la República Bolivariana de Venezuela. Disponível em:< http://www.cne.gob.ve/web/normativa_electoral/constitucion/indice.php>. Acesso em: 04 abr. 2016.

Constitución del Ecuador. Disponível em:< http://www.asambleanacional.gov.ec/documentos/constitucion_de_bolsillo.pdf >. Acesso em: 04 abr. 2016.

Constitución Nacional del Paraguay. Disponível em:< http://www.oas.org/juridico/spanish/par_res3.htm>. Acesso em: 04 abr. 2016.

Constitución Política de 1982, Honduras. Disponível em:< http://www.poderjudicial.gob.hn/CEDIJ/Leyes/Documents/Constituci\%C3\%B3n\%20de\%20la\%2 0Rep\%C3\%BAblica\%20de\%20Honduras\%20(Actualizada\%202014).pdf>. Acesso em: 04 abr. 2016. 
Constitución Política de la Republica de Chile. Disponível em:< https://www.camara.cl/camara/media/docs/constitucion_politica.pdf>. Acesso em: 04 abr. 2016.

Constitución Política de la Republica de Costa Rica. Disponível em:< http://www.google.com.br/url?sa=t\&rct=j\&q=\&esrc=s\&source=web\&cd=1\&cad=rja\&uact=8\&v ed=0CB0QFjAAahUKEwikrZS2j4jGAhUKGIwKHZNQALI\&url=http\%3A\%2F\%2Fwww.hcost arica.fcs.ucr.ac.cr\%2Fcontenidos\%2Ftextos\%2Fconstituc.rtf\&ei=RL95VaT7JoqwsASToYGQC w\&usg=AFQjCNEipQi1rgTi8APpOMuTeDrcQOgdcA\&sig2=ElHH0TrOjzr5g1BwQMmZ4g\&b vm=bv.95277229,d.cWc>. Acesso em: 04 abr. 2016.

Constitución Política de la Republica de Panama. Disponível em:< http://www.unesco.org/culture/natlaws/media/pdf/panama/pan_constpol_04_spaorof>. Acesso em: 04 abr. 2016.

Constitución Política del Estado Plurinacional de Bolivia. Disponível em:< http://www.harmonywithnatureun.org/content/documents/159Bolivia\%20Consitucion.pdf>. Acesso em: 04 abr. 2016.

Constitución Política del Peru. Disponível em:< http://www4.congreso.gob.pe/ntley/Imagenes/Constitu/Cons1993.pdf>. Acesso em: 04 abr. 2016.

Constitución Política de Nicaragua. Disponível em:< http://legislacion.asamblea.gob.ni/Normaweb.nsf/3133c0d121ea3897062568a1005e0f89/06c0db 3b7bcfc75706257307006f6c6d?OpenDocument>. Acesso em: 04 abr. 2016.

Constitution de la République d'Haïti. Disponível em:< http://parliament.gov.gy/constitution.pdf>. Acesso em: 04 abr. 2016.

Constitución Política de Colombia. Disponível em<http://www.procuraduria.gov.co/guiamp/media/file/Macroproceso\%20Disciplinario/Constitu cion_Politica_de_Colombia.htm>. Acesso em: 04 abr. 2016.

Constitución de la Republica Oriental del Uruguay. Disponível em: <http://www.rau.edu.uy/uruguay/const97-1.6.htm>. Acesso em: 04 abr. 2016.

Constitución Política de la Republica de Guatemala. Disponível em: $\langle$ https://www.oas.org/juridico/mla/sp/gtm/sp_gtm-int-text-const.pdf $>$. Acesso em: 04 abr. 2016.

Constitución Política de los Estados Unidos Mexicanos. Disponível em: <http://www.diputados.gob.mx/LeyesBiblio/htm/1.htm>. Acesso em: 04 abr. 2016.

Constitución de la Ciudad Autónoma de Buenos Aires. Disponível em:< http://infoleg.mecon.gov.ar/?page_id=166>. Acesso em: 04 abr. 2016.

Constitución de la Nación Argentina. Disponível em:〈http://www.senado.gov.ar/deInteres $>$. Acesso em: 04 abr. 2016. 
Convenção de Direito Internacional Privado de 1928. Disponível em:< http://www2.camara.leg.br/legin/fed/decret/1920-1929/decreto-18871-13-agosto-1929-549000publicacaooriginal-64246-pe.html>. Acesso em: 04 abr. 2016.

Corte Constitucional da Colombia. Sentencia S-238/06. Disponível em:< http://corteconstitucional.gov.co/relatoria/2006/C-238-06.htm>. Acesso em: 04 abr. 2016.

DAHRENDORF, R. O conflito social moderno: um ensaio sobre a política de liberdade. Rio de Janeiro: Zahar, 1992.

Declaração Universal dos Direitos Humanos de 1948. Disponível em: $\leq$ http://www.ohchr.org/EN/UDHR/Documents/UDHR_Translations/por.pdf $>$. Acesso em: 04 abr. 2016.

DAHL, Robert A., Poliarquia: participação e oposição. São Paulo: Editora da Universidade de São Paulo, 2005.

DOUZINAS, Costa. O fim dos direitos humanos. São Leopoldo: Unisinos, 2009.

EMMERICH, Norberto. El voto de los estranjeros en la republica argentina: uma ilusion pasejera. Disponível em:< http://www.alice-comunicacionpolitica.com/abrirponencia.php?f=494-F540fda9b4941410325147-ponencia-1.pdf>. Acesso em: 04 abr. 2016.

FERREIRA FILHO, Manoel Gonçalves. O poder constituinte. 3. ed. rev. e atual. São Paulo: Saraiva, 1999.

HÄBERLE, Peter. Hermenêutica constitucional: a sociedade aberta dos intérpretes da constituição: contribuição para a interpretação pluralista e "procedimental" da constituição. Tradução Gilmar Ferreira Mendes. Porto Alegre: Sergio Antonio Fabris, 1997.

HÄBERLE, Peter. Estado constitucional cooperativo. Rio de Janeiro: Renovar, 2007.

HAYDUK, Ron. Democracy for all: restoring immigrant voting rights in the United States. New York: Routledge, 2006.

KANT, Immanuel. À paz perpétua. Porto Alegre: L\&PM, 2008.

Ley 1585 de 1994, Congresso da Bolívia. Disponível em:<http://www.lexivox.org/norms/BO-L1585.xhtml>. Acesso em: 04 abr. 2016.

Ley 26.864, de 1997, Congresso de Peru. Disponível em: $\langle$ http://pdba.georgetown.edu/Electoral/Peru/municipales.pdf $>$. Acesso em: 04 abr. 2016.

Ley 25.871, de 2004. Congresso da Argentina. Disponível em: <http://infoleg.mecon.gov.ar/infolegInternet/anexos/90000-94999/92016/norma.htm $>$.

Acesso em: 04 abr. 2016.

Ley 1.070, de 2006, Congresso de Colombia. Disponível em:< http://www.alcaldiabogota.gov.co/sisjur/normas/Norma1.jsp?i=20871>. Acesso em: 04 abr. 2016. 
Ley 14.086, de 2009, Senado e Camara de Deputados da Provincia de Buenos Aires. Disponível em: <http://www.juntaelectoral.gba.gov.ar/docs/LEY14086.pdf>. Acesso em: 04 abr. 2016.

Ley $\mathrm{n}^{\mathbf{0}}$ 026, de 2010. Asamblea Legislativa Plurinacional da Bolívia. Disponível em:< http://pdba.georgetown.edu/Electoral/Bolivia/Ley26-2010.pdf>. Acesso em: 04 abr. 2016.

MISES, Ludwig von. Theory and history. Connecticut: Yale University Press, 1957.

OEA. Migración internacional em las Américas: tercer informe del sistema continuo de reportes sobre migración internacional em las américas (SICREMI). Disponível em: $<$ http://www.oas.org/docs/publications/SICREMI-2015-SPANISH.pdf $>$. Acesso em: 07 maio 2016.

ONU. PNUD. Transformando Nosso Mundo: A Agenda 2030 para o Desenvolvimento

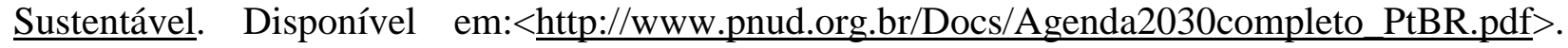
Acesso em: 24 abr. 2016.

Pacto Internacional sobre Direitos Civis e Políticos de 1966. Disponível em: $<$ http://www.planalto.gov.br/ccivil_03/decreto/1990-1994/d0592.htm>. Acesso em: 04 abr. 2016.

Proyeto de Ley S-2696 de 2012, Senado da Argentina. Disponível em:< http://www.argentinaelections.com/wp-content/uploads/2012/10/11719.pdf $>$. Acesso em: 04 abr. 2016.

SEN, Amartya. Desenvolvimento como liberdade. São Paulo: Companhia das Letras, 2010. 